\title{
Penyalahgunaan Keadaan Dalam Prosedur Permohonan Pailit Di Pengadilan Niaga
}

\author{
Ronald Saija \\ Fakultas Hukum Universitas Pattimura. Ambon, Indonesia \\ E-mail: ronaldreagensaija@gmail.com
}

\begin{abstract}
In line with the rapidly growing trade trajectory, increasing and on an increasingly widespread and global scale, where corporate debt problem is getting complicated and requires effective legal regulation. The development of the global economy today requires the rule of bankruptcy law that is able to meet the legal needs of business people in the settlement of their accounts receivable. The monetary turmoil that occurred in mid-July 1997, resulted in a very wide impact on business development in Indonesia. In the face of this kind of thing, it is of course deemed necessary to take remedial measures, especially legal certainty in order to balance the interests of the company or the interest between creditors and debtors who go bankrupt. One of the legal means underlying the settlement of accounts payable is the regulations concerning the procedure of bankruptcy petition in the Commercial Court, as stipulated in Government Regulation in Lieu of Law No. 1 of 1998 on Amendment to the Law on Bankruptcy (Faillissement Verordening), which subsequently stipulated as Law No. 4 of 1998 on Bankruptcy, then underwent changes and improvements to Law of the Republic of Indonesia Number 37 Year 2004 concerning Bankruptcy and Suspension of Payment Obligation (PKPU). However, this law is felt to be less effective and less tested, due to the abuse of circumstances of interest, the factor of rights and power status factors in the current Bankruptcy application in the Commercial Court.
\end{abstract}

Keywords: abuse of circumstances, commercial court, bankruptcy petition, creditor.

\section{A. PENDAHULUAN.}

Hukum tidak dapat dipisahkan dari budaya, sejarah dan waktu di mana kita sedang berada. Setiap perkembangan sejarah dan sosial harus diimbangi dengan perkembangan hukum, karena setiap perubahan sosial akan mempengaruhi perkembangan hukum. ${ }^{1}$ Melalui pendekatan kultur, pembinaan hukum dilihat bukan sekedar pergeseran waktu dari zaman kolonial ke zaman kemerdekaan diperlukan adanya

1 Alvi Syahrin, 2002, Beberapa Masalah tentang Hukum, Pustaka Bangsa Press, Jakarta, h. 27. 
perubahan hukum, serta pergeseran nilai yang ingin menjabarkan sistem nilai yang dianut dalam konstruksi hukum nasional. ${ }^{2}$ Implikasinya bukan saja pada kegiatan bisnis tetapi juga terhadap badan peradilan yang dianggap tidak profesional dalam menangani sengketa-sengketa bisnis. Sejalan dengan perkembangan perdagangan yang semakin cepat, meningkat dan dalam skala yang semakin luas dan global, di mana masalah utang piutang perusahaan semakin rumit dan membutuhkan aturan hukum yang efektif. Perkembangan perekonomian global dewasa ini membutuhkan aturan hukum kepailitan yang mampu memenuhi kebutuhan hukum para pelaku bisnis dalam penyelesaian utang piutang mereka.

Gejolak moneter yang terjadi pada pertengahan juli 1997, mengakibatkan dampak yang sangat luas terhadap perkembangan bisnis di Indonesia. Dalam menghadapi hal semacam ini, tentunya dipandang perlu untuk mengambil langkah-langkah perbaikan khususnya kepastian hukum guna menyeimbangkan kepentingan perusahaan ataupun kepentingan antara kreditor maupun debitor.

Salah satu sarana hukum yang menjadi landasan bagi penyelesaian utang piutang yaitu peraturan tentang prosedur permohonan pailit di Pengadilan Niaga, sebagaimana telah diatur dalam Peraturan Pemerintah Pengganti Undang-Undang Nomor 1 Tahun 1998 tentang Perubahan Atas Undang-Undang tentang Kepailitan (Faillissement Verordening), yang kemudian ditetapkan menjadi Undang-Undang Nomor 4 Tahun 1998 tentang Kepailitan, kemudian mengalami perubahan dan penyempurnaan menjadi Undang-Undang Republik Indonesia Nomor 37 Tahun 2004 tentang Kepailitan dan Penundaan Kewajiban Pembayaran Utang (selanjutnya disebut sebagai UU

2 M. Solly Lubis, 1989, Serba Serbi Politik, Mandar Maju, Bandung, h. 44.
Kepailitan). Namun Undang-Undang ini kurang efektif dan kurang teruji, karena adanya penyalahgunaan keadaan dari faktor kepentingan, hak-hak dan status kekuasaan di dalam prosedur permohonan pailit di Pengadilan Niaga.

Untuk itu, yang perlu dilakukan pengkajian pada Undang-Undang Kepailitan adalah perihal permohonan pailit harus diikuti dengan penetapan pailit bukan putusan pailit, prosedur permohonan bukan merupakan sengketa, prosedur sita umum atas harta debitor harus dilakukan secara langsung tanpa menggunakan proses litigasi (parate eksekusi), prosedur penetapan jumlah biaya pailit yang harus diberikan kepada debitor pailit masih tidak efektif dan tidak adil. Adanya perkembangan ini mengakibatkan terjadinya penyalahgunaan keadaan dalam praktik permohonan pailit di Pengadilan Niaga. Oleh kartena itu, diperlukan suatu perubahan dalam menggunakan upaya harmonisasi hukum dengan ketentuan-ketentuan yang berlaku dalam hukum acara perdata di Indonesia untuk mewujudkan kepastian hukum bagi para kreditor.

Berdasarkan uraian di atas, maka yang menjadi isu permasalahan pada problemtika dalam permohonan pailit di Pengadilan Niaga yakni: 1). Bagaimana hakim dapat menggunakan putusan pailit yang tidak taat asas sesuai dengan kriteria permohonan? 2) Bagaimanakah implementasi kepailitan bagi pihak debitor yang belum ada pembatasan nominal jumlah utang debitor pailit secara pasti?

\section{B. PEMBAHASAN}

\section{Penyalahgunaan Keadaan Pada Putusan Atau Penetapan Di Pengadilan Niaga}

Dari uraian sebelumnya bahwa bentuk sengketa kepailitan dimasukkan dalam kategori permohonan. Kendatipun 
sengketa kepailitan berbentuk permohonan, namun undang-undang sendiri menetapkan bahwa terhadapnya pengadilan memberikan keadilannya dalam bentuk suatu putusan. Putusan kepailitan adalah bersifat serta merta dan konstitutif, yakni meniadakan keadaan dan menciptakan keadaan hukum baru. Dalam putusan hakim dalam kepailitan terdapat tiga hal yaitu: 1) pernyataan bahwa si debitor pailit; 2) pengangkatan seorang hakim pengawas yang ditunjuk dari hakim pengadilan; dan 3) penetapan kurator.

Putusan hakim Pengadilan Niaga harus sudah selesai dalam waktu enam puluh hari, sejak pengajuan permohonan kepailitan. Mahkamah Agung Republik Indonesia dalam Surat Edarannya pernah menyatakan bahwa putusan hakim hanya diperuntukkan bagi pihak-pihak yang bersangkutan, sehingga akibatnya sistem peradilan tidak memiliki akuntabilitas publik, karena masyarakat tidak bisa menilai putusan-putusan yang dibuat oleh hakim. Sementara itu, sistem pengawasan dari dalam lembaga peradilan sendiri sudah tidak bisa diharapkan.

Upaya hukum yang dapat diajukan terhadap putusan atas permohonan pernyataan pailit adalah Kasasi ke Mahkamah Agung yang permohonannya diajukan paling lambat delapan hari, setelah tanggal putusan yang dimohonkan Kasasi siucapkan, dengan mendaftarkan kepada Panitera Pengadilan Niaga yang telah memutus permohonan pernyataan pailit. Permohonan kasasi, selain dapat diajukan oleh debitor dan kreditor yang merupakan pihak pada persidangan tingkat pertama, juga dapat diajukan oleh kreditor lain yang bukan merupakan pihak pada persidangan tingkat pertama yang merasa tidak puas terhadap putusan atas permohonan pernyataan pailit. Dalam hal ini, Mahkamah Agung wajib mempelajari permohonan kasasi dan menetapkan hari sidang paling lambat dua hari setelah tanggal permohonan kasasi diterimanya. $^{3}$

Sidang pemeriksaan atas permohonan kasasi dilakukan paling lambat dua puluh hari, setelah tanggal permohonan kasasi diterima oleh Mahkamah Agung dan putusan atas permohonan kasasi tersebut diucapkan paling lambat enam puluh hari setelah tanggal penerimaan permohonan kasasi. ${ }^{4}$ Selanjutnya terhadap putusan yang telah memperoleh kekuatan hukum tetap, dapat diajukan permohonan peninjauan kembali kepada Mahkamah Agung. ${ }^{5}$ Pengajuan peninjauan kembali dilakukan dalam jangka waktu paling lambat seratus delapan puluh hari setelah tanggal putusan yang dimohonkan peninjauan kembali memperoleh kekuatan hukum tetap, apabila setelah perkara diputus ditemukan bukti baru yang bersifat menentukan pada waktu perkara diperiksa di pengadilan belum ada ditemukan. ${ }^{6}$ Sedangkan pengajuan permohonan peninjauan kembali dilakukan dalam jangka waktu paling lambat tiga puluh hari setelah tanggal putusan yang dimohonkan peninjauan kembali memperoleh kekuatan hukum tetap, apabila dalam putusan hakim yang bersangkutan terdapat kekeliruan yang nyata. $^{7}$

Dalam jangka waktu paling lambat tiga puluh hari setelah tanggal permohonan diterima oleh panitera Mahkamah Agung, maka Mahkamah Agung segera memeriksa dan memberikan putusan atas permohonan peninjauan kembali tersebut. ${ }^{8}$ Salinan putusan peninjauan kembali yang memuat secara lengkap pertimbangan hukum yang mendasari putusan tersebut wajib disampaikan oleh Mahkamah

3 Pasal 133 UU Kepailitan.

4 Pasal 133 ayat (2) dan (3) UU Kepailitan.

5 Pasal 295 UU Kepailitan.

6 Pasal 296 ayat (1) UU Kepailitan.

7 Pasal 296 ayat (2) UU Kepailitan.

8 Pasal 298 ayat (1) UU Kepailitan. 
Agung kepada para pihak dalam jangka waktu paling lambat tiga puluh hari setelah tanggal permohonan diterima oleh penitera Mahkamah Agung. ${ }^{9}$

Dalam putusan pailit diangkat hakim pengawas dan kurator. ${ }^{10}$ Hakim pengawas adalah hakim yang ditunjuk oleh pengadilan dalam putusan pailit atau putusan penundaan kewajiban pembayaran utang; tugas dari hakim pengawas adalah mengawasi pengurusan dan pemberesan harta pailit. ${ }^{11}$ Di samping itu, hakim pengawas berwenang untuk mendengar keterangan saksi atau memerintahkan menyediakan oleh para ahli untuk memperoleh kejelasan tentang segala hal mengenai kepailitan.

Kurator dapat melakukan kewajiban pengutrusan dan/atau pemberesan harta pailit, meski ada kasasi ataupun peninjauan kembali.kurator yang dimaksud di sini adalah Balai Harta Peninggalan (BHP) dan Kurator lainnya. ${ }^{12}$ Apabila putusan pailit kemudian dibatalkan sebagai akibat kasasi atau peninjauan kembali, maka semua tindakan hukum yang dilakukan oleh kurator sebelumnya atau pada tanggal kurator menerima pemberitahuan pembatalan putusan tersebut tetap bertanggung jawab atas kesalahan atau kelalaiannya dalam kelalaiannya dalam melakukan tugas pengurusan dan/ atau pemberesan yang menyebabkan kerugian terhadap harta pailit.

Semua penetapan mengenai pengurusan dan/atau pemberesan harta pailit ditetapkan oleh pengadilan dalam tingkat terakhir kecuali undang-undang ini menentukan lain. sifat putusan dalam Undang-Undang Kepailitan dapat dilaksanakan lebih dahulu (uit verbaar bij voorraad). Dengan demikian dilakukannya upaya hukum tidak menghentikan pelaksanaan dari putusan.

\footnotetext{
9 Pasal 298 ayat (3) UU Kepailitan.

10 Pasal 15 ayat (1) UU Kepailitan jo. Pasal 13 ayat (1) UU Kepailitan.

11 Pasal 65 UU Kepailitan.

12 Pasal 70 ayat (1) UU Kepailitan.
}

Menurut analisa penulis bahwa putusan pailit yang diterapkan dalam permohonan pailit sesuai dengan UU RI No. 37 Tahun 2004 jo. UU RI No. 4 Tahun 1998 jo. Perpu No. 1 Tahun 1998, tidak taat asas sehingga terjadi penyalahgunaan keadaaan dalam permohonan pailit, sebab ditunggangi dengan faktor kepentingan, faktor hak-hak dan faktor status kekuasaan.

Permohonan pailit harus diikuti dengan penetapan pailit, sehingga defenisi pailit dalam Pasal 1 ayat (1) UU Kepailitan terpenuhi. Adanya "sita umum atas semua kekayaan debitor pailit..." mendeskripsikan bahwa permohonan pailit harus dilakukan dengan penetapan pailit, sehingga menghasilkan parate eksekusi yang mengikat dan final di Pengadilan Niaga tanpa adanya upaya hukum kasasi dan peninjauan kembali di Mahkamah Agung yang memperpanjang waktu prosesnya. Berdasarkan hal di atas, maka menurut penulis bahwa harus ada "revisi" terhadap prosedur permohonan pailit di Pengadilan Niaga khususnya "Putusan" harus digantikan dengan "Penetapan", sehingga kepentingan para kreditor atas harta kekayaan debitor pailit dapat diselesaikan secara cepat, efektif dan efisien sesuai dengan asas keseimbangan, asas kelangsungan usaha, asas keadilan dan asas integrasi.

\section{Penyalahgunaan Keadaan Pada Penetapan Pembatasan Nominal Jumlah Utang Dalam Pengadilan Niaga}

.Dalam proses acara kepailitan konsep utang sangat menentukan, oleh karena tanpa adanya utang tidaklah mungkin perkara kepailitan akan bisa diperiksa. Tanpa adanya utang, maka esensi kepailitan menjadi tidak ada kerena kepailitan merupakan pranata hukum untuk melakukan likuidasi aset debitor membayar utang-utangnya terhadap para kreditornya. Utang merupakan dasar utama untuk mempailitkan subjek hukum yang sangat 
penting dikaji lebih lanjut mengenai prinsip yang mendasari norma utang tersebut. Pailit bersumber dari adanya utang yang tidak dibayarkan. Dalam perspektif ekonomi, utang adalah sesuatu yang dituangkan oleh seseorang kepada orang lain termasuk uang, barang-barang, atau jasa-jasa. ${ }^{13}$

Henry Campbell Black mendefinisikan utang adalah sejumlah uang di mana seseorang berkewajiban dan menyatakan persetujuannya. Suatu jumlah uang tertentu yang dipinjamkan kepada seorang dari orang lainnya, termasuk didalamnya debitor tidak hanya berkewajiban untuk membayar tetapi juga menjadi hak kreditor untuk menerima kembali uangnya dan memaksa debitor membayar utang itu. ${ }^{14}$

Inti dari pengertian utang dari beberapa definisi di atas adalah adanya kewajiban dari satu pihak kepada pihak lain untuk melakukan pembayaran sejumlah uang, barang-barang atau jasa-jasa pada waktu yang telah ditentukan sesuai dengan yang diperjanjikan. Utang tersebut dapat dijaminkan maupun tidak dijaminkan, dapat dikenakan bunga maupun tidak dikenakan bunga.

Praktik peradilan dalam masalah kepailitan sebelum berlakunya UU RI No. 4 Tahun 1998 tentang Kepailitan, pada umumnya mengendalikan bahwa suatu utang adalah pinjaman uang baik tunai maupun kredit, baik yang dilakukan oleh kreditor perorangan maupun kreditor yang berbentuk badan hukum yang umumnya adalah bank. ${ }^{15}$

Padahal perkembangan ekonomi yang demikian pesat membawa pengaruh

13 John Downes dan Jordan Elliot Goodman terjemahan Sudanto budidarmo, 1994, Kamus Istilah Keuangan dan Investasi, Gramedia, Jakarta, h. 128.

14 J. Satrio, 1996, Perikatan Tentang Hapusnya Perikatan, Bagian II, Citra Aditya Bakti, Bandung, h. 69.

15 Abdulkadir Muhammad, 1998, Hukum Dagang Tentang Surat-Surat Berharga, Citra Aditya Bakti, Bandung, h. 155, 160. dan perubahan yang cepat terhadap transaksi-transaksi yang dilakukan oleh para pihak, sehingga membawa dampak terhadap pengertian utang. Hal itu dapat dilihat dari beberapa putusan Pengadilan Niaga setelah berlakunya UU RI No. 4 Tahun 1998 tentang Kepailitan, terutama pada tahun pertama berlakunya Undang-Undang tersebut tahun 1998, yang mendalilkan utang antara lain:

1) Utang yang muncul akibat perjanjian jual beli satuan rumah susun.

2) Utang yang muncul akibat perjanjian pinjam uang, akta pengakuan utang dan pinjaman kredit rekening Koran (revolving);

3) Utang yang timbul dari jaminan pribadi debitor terhadap perjanjian kredit.

4) Utang berasal dari penerbitan surat sanggup (promissory note). ${ }^{16}$

5) Utang karena kredit sindikasi dan facility agreement dalam bentuk roll over falicity agreement.

Kriteria ini dapat dikategorikan menjadi utang dalam perkembangan terakhir terus bertambah dan semakin beragam, seiring dengan bertambah banyaknya cara dan bentuk-bentuk hubungan hukum yang dilakukan oleh para pihak dalam lalu lintas perdagangan maupun transaksi-transaksi lainnya baik antara orang perorangan dengan badan hukum, badan hukum dengan badan hukum, maupun badan hukum dengan orang.

Sutan Remy Sjahdeini berpendapat lain, bahwa batas minimal besarnya utang harus ditentukan, karena apabila piutang yang tidak dibayar dibatasi akan sangat merugikan debitor yang selanjutnya akan sangat merugikan para pemegang saham dari debitor, misalnya seorang debitor

16 Tempo, Edisi 19-26 Januari 1999, h. 
dengan aset Rp. 1.000.000.000.000,00 dapat diajukan pailit oleh seorang kreditor yang hanya memiliki tagihan misalnya Rp. 10.000.000,00. ${ }^{17}$

Pendapat yang tidak setuju dengan adanya pembatasan jumlah minimal utang sebagai syarat diajukannya pernyataan pailit adalah dengan alasan untuk memberikan perlindungan hukum bagi kreditor kecil, di mana dengan jumlah utang yang sebetulnya tidak seberapa dibandingkan dengan aset yang dimiliki debitor, justru piutang kreditor yang kecil itu merupakan sumber modal bagi beroperasinya perusahaan atau usaha kreditor, sehingga dengan tidak dibayarnya piutang tersebut, maka kreditor akan mengalami kesulitan untuk menjalankan usahanya.

Kriteria utang yang dapat ditagih pun tidak terdapat dalam ketentuan yang menjelaskan jatuh tempo utang itu, apakah harus secara keseluruhan artinya semua jumlah utang telah jatuh tempo, ataukah hanya sebagian dari jumlah utang yang harus dibayar. Misalnya suatu perusahaan yang terus menerus berproduksi namun tidak dapat memperoleh laba, sehingga kalaupun mampu membayar utangnya yang telah jatuh tempo hanya dibayar secara berangsur. Tidak penuhnya pembayaran utang ini dapat dimasukan sebagai kriteria utang sebagaimana diatur dalam ketentuan Pasal 1 ayat (1) UU Kepailitan. Hal yang menarik dari perdebatan tentang utang adalah pendapat yang memberikan kesempatan kepada para kreditor dan debitor melakukan kompromi sebelum gugatan diadili di Pengadilan Niaga.

Menurut penulis, pailit dapat dihubungkan dengan berhentinya pembayaran dari seseorang (debitor) atas utang-utangnya yang telah jatuh tempo, dan berhentinya pembayaran harus disertai dengan suatu tindakan nyata untuk mengajukan, baik dilakukan secara sukarela oleh debitor sendiri maupun atas permintaan pihak ketiga. Keadaan berhenti membayar utang dapat terjadi karena tidak mampu membayar atau tidak mau membayar. Dalam keadaan pailit, seorang debitor telah berhenti membayar utang-utangnya, dan atas permintaan para kreditornya, atau permintaan sendiri oleh pengadilan dinyatakan pailit dan harta kekayaan dikuasai oleh balai harta peninggalan selaku pengampu dalam usaha kepailitan untuk dimanfaatkan oleh semua kreditor.

Kedua penyebab terjadinya pemberhentian pembayaran pada dasarnya adalah sama, yaitu menimbulkan kerugianbagi kreditor. Di pihak lain, debitor juga dapat mengalami kesulitan untuk melanjutkan usaha (asas kelangsungan usaha) terutama dalam hubungan masalah keuangan. Untuk mengatasi hal tersebut, debitor dapat mengambil berbagai tindakan meliputi perundingan langsung dengan kreditor, perdamaian dan alternatif penyelesaian sengketa untuk menjadwalkan kembali pembayaran atau menunda pemenuhan kewajiban pembayaran, atau kepailitan. Menurut penulis, cara-cara penyelesaian melalui jalur tersebut diharapkan dapat menjamin keamanan dan kepentingan para pihak yang bersangkutan. Perkara kepailitan merupakan suatu jalan keluar yang bersifat komersial untuk keluar dari persoalan utang piutang yang menghimpit seorang debitor, sehingga debitor tersebut tidak mempunyai kemampuan lagi untuk membayar utang-utangnya kepada para kreditornya.dalam hal ini, tujuan kepailitan adalah untuk melakukan pembagian antara para kreditor atas kekayaan debitor oleh kurator, dan/atau kepailitan dimaksudkan untuk menghindari terjadinya sitaan terpisah atau eksekusi terpisah oleh kreditor dan menggantikannya dengan mengadakan sitaan bersama, sehingga kekayaan debitor dapat dibagikan kepada semua kreditor sesuai dengan hak masing-masing. 
Menurut penulis, dalam perkara kepailitan yang dibuktikan hanya kebenaran ada atau tidaknya suatu utang dapat dijadikan dasar untuk mengabulkan atau menolak permohonan pailit yang diajukan ke Pengadilan Niaga. Dalam praktiknya, kebenaran akan dibuktikan pada beberapa kasus kepailitan adalah kebenaran tentang hubungan hukum menyebabkan terjadinya permasalahan hukum yang perlu diselesaikan secara adil, bukan untuk dipailitkan.

Menurut penulis bahwa tidak terdapatnya pembatasan jumlah nilai nominal utang di dalam pengajuan permohonan pernyataan pailit di Pengadilan Niaga. Karena belum adanya pembatasan nilai nominal utang sebagai kekurangan dan kelemahan aturan hukum kepailitan di Indonesia saat ini, sehingga dapat dikategorikan sebagai perbuatan penyalahgunaan keadaan bagi pihak kreditor terhadap pihak debitor.

Jika kita melakukan perbandingan hukum, maka pembatasan jumlah nilai nominal utang di dalam pengajuan permohonan pernyataan pailit merupakan suatu kelaziman sebagaimana dianut di beberapa negara lain seperti Singapura, Hongkong, Filipina, Australia, Kanada, dan Amerika Serikat, Dalam Undang-Undang Kepailitan Singapura mengatur jumlah minimal utang yang dapat diajukan pailit adalah sebesar US\$ 2.000,00 atau jumlah lain akan ditentukan di kemudian hari. Di Hongkong, perusahaan yang tidak dapat memenuhi kewajibannya untuk jumlah utang lebih dari HK\$ 5.000,00. Sedangkan The Philippine Act, tiga orang kreditor atau lebih yang merupakan penduduk Filipina dan memiliki tagihan terhadap debitor hingga mencapai nilai sebesar 1.000,00 peso dapat mengajukan permohonan pernyataan pailit. Di Australia pengajuan permohonan pernyataan pailit tidak disyaratkan besaran jumlah utang yang dimiliki, sedangkan pengajuan permohonan pernyataan pailit atau penitipan barang atas perintah Pengadilan (sequestration) dilakukan apabila debitor memiliki utang tidak kurang dari AUS\$ 2.000,00 dalam bentuk utang yang jumlahnya telah ditentukan dalam perjanjian. Di Kanada, kreditor tidak berjaminan atau kreditor yang berjaminan mempunyai piutang senilai CND\$ 1.000,00 dapat mengajukan permohonan pailit dalam jangka waktu enam bulan dari saat debitor mengajukan permohonan kepada The Official Receiver. Bankruptcy Code Amerika Serikat mensyaratkan permohonan pernyataan pailit dapat diajukan jika debitor memiliki tagihan yang tidak berjaminan (unsecured debt) sebesar US\$ 5.000,00. Tiga kreditor harus bersama-sama mengajukan permohonan pailit, apabila debitor memiliki dua belas kreditor atau lebih, sebaliknya seorang kreditor dapat mengajukan permohonan pailit sepanjang tagihannya minimal US\$ 5.000,00.

Menurut penulis, kepailitan bukanlah semata sebuah upaya untuk mempermudah sebuah usaha, baik itu milik perorangan maupun berbentuk korporasi menjadi bangkrut, melainkan kepailitan adalah salah satu upaya untuk mengatasi kebangkrutan sebuah usaha. Menarik untuk bercermin pada Insolvency Act 1986 di Inggris yang memfasilitasi budaya penyelamatan perusahaan yaitu corporate resque adalah sebelum suatu perusahaan mengalami kesulitan keuangan dinyatakan pailit harus dilakukan penyelamatan terlebih dahulu. Pada hakikatnya adalah suatu intervensi utama yang dibutuhkan untuk "mencegah kegagalan perusahaan". Penulis sependapat dengan konsep penyelamatan korporasi, terhadap debitor yang berpotensi dan prospektif. Namun, terhadap debitor yang mengalami kesulitan keuangan sehingga tidak dapat memenuhi kewajibannya membayar utang-utangnya, kepailitan adalah jalan terbaik, meskipun dalam mekanisme kepailitan tidak menutup kemungkinan perusahaan tetap beroperasi, berdasarkan 
persetujuan kurator, para kreditor atau panitia kreditor, atau hakim pengawas berdasarkan pertimbangan perusahaan masih prospektif.

Menurut analisa penulis bahwa harus ada penetapan jumlah utang bagi debitor yang dinyatakan pailit oleh para kreditor, sehingga ada kejelasan hukum mengenai "status pailit debitor". Hal ini dapat memberikan "solusi" dalam mengkaji Undang-Undang Kepailitan kemudian hari, tanpa adanya penyalahgunaan keadaan bagi pihak-pihak yang merasa berkepentingan. Menurut penulis, untuk pembatasan nomimal jumlah utang bagi debitor dinyatakan pailit sebesar Rp. 200.000.000,00 yang harus dikaji dalam UU Kepailitan dikemudian hari

\section{PE N U T P}

Putusan pailit dalam permohonan pailit yang diatur dalam Undang-Undang Kepailitan "tidak taat asas", sehingga "tidak mendasar" atau "rancu". Adanya kejelasan terhadap klarifikasi jumlah utang bagi debitor pailit, sehingga jelas proses permohonan pailit di Pengadilan Niaga, seperti pada Amerika Serikat, Australia, Singapura dan Hongkong.

Diharapkan adanya revisi pada penerapan putusan atas permohonan pailit di Pengadilan Niaga bersifat mengikat dan final, sehingga taat asas sesuai dengan aturan hukum yang ada. Perlu juga dilakukan revisi pada pembatasan nomimal jumlah utang debitor yang akan dinyatakan pailit sebesar Rp. 200.000.000,00 sehingga ada kejelasan mengenai jumlah utang yang dinyatakan telah jatuh waktu untuk dipailitkan. Suatu pengkajian mengenai judul undang-undang juga perlu dilakukan agar proses "permohonan" pailit tidak digabungkan dengan "sengketa" pailit. Pada akhirnya perlu ditinjau kembali prosedur permohonan pailit, terutama jangka waktu, eksepsi, replik, duplik dan kesimpulan agar tidak disamakan dengan gugatan di Pengadilan Negeri (Peradilan Umum).

\section{DAFTAR PUSTAKA}

Downes, John dan Goodman, Jordan Elliot terjemahan Sudanto Budidarmo, Kamus Istilah Keuangan dan Investasi, Gramedia, Jakarta, 1994.

Lubis, M. Solly, 1989, Serba Serbi Politik, Mandar Maju, Bandung.

Mahkamah Agung Republik Indonesia, Kumpulan Makalah Calon Hakim Pengadilan Niaga, Jakarta, 1998.

Mertokusumo, Sudikno, 1998, Hukum Acara Perdata Indonesia, Liberty, Yogyakarta.

Muhammad, Abdulkadir, 1998, Hukum Dagang Tentang Surat-Surat Berharga, Citra Aditya Bakti, Bandung.

Muljadi, Kartini dan Widjaja, Gunawan, 2004, Pedoman Menangani Perkara Kepailitan, Raja Grafindo Pesada, Jakarta.

Nasir, M., 2003, Hukum Acara Perdata, Djambatan, Jakarta.

Satrio, J., 1996, Perikatan Tentang Hapusnya Perikatan, Bagian II, Citra Aditya Bakti, Bandung.

Sjahdeini, Sutan Remy, 2002, Hukum Kepailitan: Memahami Faillissementsverordening juncto Undang-Undang Nomor 4 Tahun 1998, Pustaka Utama Grafiti, Jakarta.

Suyudi, Aria et al., 2004, Kepailitan di Negeri Pailit, Pusat Studi Hukum dan Kebijakan Indonesia, Jakarta.

Syahrin, Alvi, 2002, Beberapa Masalah tentang Hukum, Pustaka Bangsa Press, Jakarta.

Tempo, Edisi 19-26 Januari 1999. 